\title{
Paulo diante do cristianismo nascente
}

\author{
Dom José Antônio Peruzzo
}

\section{Introdução}

Estudar um tema como "Paulo diante do cristianismo nascente", é sem dúvida um tema apaixonante, que sempre desperta interesse. A história do maior protagonista do cristianismo dos primeiros tempos, suas experiências pessoais, suas aventuras e desventuras ministeriais, suas crises com algumas comunidades, ou com setores determinados do cristianismo nascente, seu vigor missionário, seu caudal teológico imenso, ou sua sensibilidade pastoral, ofereceriam muitos ângulos de análise e de interpretação. $\mathrm{O}$ cidadão romano, mas de origem e formação judaica muito aprofundada, porém habilitado a brandir com maestria a arte discursiva e cultural grega, será sempre motivo de investigação e de novas compreensões ante os novos desafios do cristianismo do nosso tempo.

O tema que me foi proposto fascina, mas também requer delimitação. Em relação ao cristianismo nascente Paulo foi absolutamente singular. Entre outros enfoques poderíamos dizer que atuou como fundador, como evangelizador, como pastor, como educador da fé, como sistematizador, como autor teológico... De sua reflexão teológica dirigida aos cristãos do seu tempo se poderia privilegiar a missionariedade, mas também sua antropologia é muito rica, ou sua originalidade sobre a cristologia, também seu pensamento sobre a escatologia é bastante fecundo. Também a ética paulina suscitou muitas revisões de comportamentos aos leitores do seu tempo. 
É preciso fazer uma escolha. Dado que Paulo é filho do cristianismo nascente, e suas experiências pessoais de tornar-se cristão foram decisivas, quer para seu ministério, quer para suas elaborações teológicas, pareceu-me interessante lançar um olhar para a sua relação pessoal com Jesus Cristo e de que maneira tal intimidade com o Senhor Jesus conferiu sentido às suas motivações apostólicas. Mais do que falar do teólogo, aqui se quer vislumbrar o homem de fé, o seguidor de Jesus Cristo, que por causa do seu Senhor percorreu com Ele os mesmos caminhos. Com isso não se pretende reapresentar as vivências místicas do apostolo. O objetivo é outro, é mostrar como suas experiências de fé se tornaram substrato para grande parte dos seus escritos.

A apresentação que segue terá três partes. A primeira tentará traduzir o que significou para o apóstolo o seu encontro com Jesus Cristo e os desdobramentos, para o cristianismo nascente, derivados daquele encontro. A segunda, mais breve, salientará como a centralidade de Jesus Cristo inspirou suas reflexões face à problemática judaizante, uma vez que esta foi uma das questões mais espinhosas no ministério de Paulo. Na terceira parte se buscará evidenciar as respostas centrais de Paulo aos anseios humanos latentes nas comunidades, quer de origem grega, quer de origem judaica. Para todos os caminhos levavam a uma única aceitação nuclear: a cruz de Cristo.

\section{Aspectos fundantes da vida pessoal de cristão}

\subsection{A experiência próxima a Damasco}

\subsubsection{As narrações}

As primeiras imagens que afloram à mente quando se pensa na conversão e/ou vocação de Paulo é aquela presente em At 9,1-19a. É a grande mudança na vida de Paulo. Toda a sua existência pessoal passa, a partir de então, por uma profunda e total transformação. Para Lucas, autor do livro dos Atos, não se tratou apenas de um acontecimento ligado a alguma forma de evolução psicológica ou religiosa do interessado, mas de uma intervenção direta e envolvente de Cristo Ressuscitado ${ }^{1}$. O que aconteceu nas vizinhanças de Damasco faz parte de um plano divino. A importância de tal evento

\footnotetext{
${ }^{1}$ A composição de At 9,1-19a refere duas visões sucessivas, de estrutura paralela (vv. 3-9.1016). Tal paralelismo está narrativamente orientado a aproximar Ananias de Saulo. O objetivo teológico é evidenciar a iniciativa divina de tal encontro. Estruturação muito semelhante pode ser visto no capítulo seguinte (conversão de Cornélio / At 10,1-48). Isso sugere a intervenção redacional do autor. Para explicações detalhadas ver ROSSÉ, G.; Atti degli Apostoli. Commento Esegetico e Teológico, Roma: Città Nuova, 1998, pp. 364-379.
} 
recebeu tanto destaque no livro dos Atos que chega a ser reapresentado ainda outras duas vezes (At 22,3-21; 26,4-23). Nestes últimos dois casos o Paulo lucano narra sua experiência em tom autobiográfico. Trata-se de pronunciamentos de Paulo, o primeiro ante o povo judeu no templo de Jerusalém, após o seu aprisionamento (At 22,3-21); já o segundo foi diante do rei Agripa, da irmã deste, Berenice, e ainda diante do procurador Festo (At 26,2-23).

Coletando os dados das três narrativas é possível compor a seguinte seqüência: Paulo, munido de cartas do sumo sacerdote, deveria proceder com dureza com os judeus de Damasco que se fizeram cristãos $(9,2)$. Ao aproximar-se da cidade, ao meio dia, repentinamente, foi envolvido por uma luz vinda do céu $(22,6$ : “... brilhou ao redor de mim"; $(26,13$ : “... mais brilhante que o sol... circundou a mim e aos que me acompanhavam"). Paulo caiu por terra $(9,4 ; 26,14$ : também seus acompanhantes). Jesus Cristo se deu a conhecer mediante uma voz. Somente Paulo a ouviu $(9,4 ; 22,7 ; 26,13)$. O Senhor lhe ordenou que fosse à cidade; lá lhe seria dito o que deveria fazer. Por causa da luz, Paulo se tornou cego. Um certo Ananias, um judeu cristão de Damasco, recebeu do Senhor a ordem de dirigir-se até Paulo, que "está em oração" (9,11c). Quando Ananias lhe impôs as mãos, Paulo recobrou a vista, recebeu o Espírito Santo e foi batizado $(9,17 \mathrm{~s})$.

Em nenhum momento do seu epistolário Paulo explicita o que lhe aconteceu realmente em Damasco. Limita-se a freqüentes alusões. Deixa entrever que suas comunidades sabem o que se passou. Quando ele se qualifica de "apóstolo por vocação" (Rm 1,1), "apóstolo de Cristo Jesus por vontade de Deus" (1Cor 1,1), "apóstolo das nações" (Rm 11,13), "apóstolo - não por parte dos homens, nem por intermédio de um homem, mas por Jesus Cristo e Deus Pai..." (Gl 1,1), está ele a indicar que o ocorrido tinha um conteúdo vocacional.

Quanto ao modelo narrativo dos acontecimentos de Damasco, apresentados no livro dos Atos, Lucas parece ter seguido um esquema já presente nas histórias judaicas de conversão. A mais semelhante é a de Heliodoro. Este primeiro ministro de Seleuco IV recebeu do rei a ordem de se apoderar dos tesouros do templo de Jerusalém. Ao entrar no templo uma luz do céu o impediu de realizar seu intento. Caiu por terra e uma escuridão profunda o envolveu. Então desistiu do empreendimento, confessou-se pecador e prometeu anunciar a todos os homens a grandeza daquele lugar sagrado ${ }^{2}$.

Mais do que buscar elementos que permitam interpretar descritivamente o que ocorreu nas proximidades da capital síria, vale observar o que

\footnotetext{
${ }^{2}$ Gnilka, J., Pablo de Tarso, apóstol y testigo, Barcelona: Herder, 1998, pp. $43-46$ apresenta informações bastante elucidativas acerca dos estudos relativos a relatos de vocação dos ambientes religiosos judaicos, que, provavelmente, serviram de modelo para Lucas.
} 
Paulo relata aos judeus de Jerusalém. Em At 22,17-18.21 ele está a falar do que the acontecera. E acrescenta: "Depois, tendo eu voltado a Jerusalém, orando no templo, sucedeu-me entrar em êxtase. E vi o Senhor que me dizia: 'Apressa-te, sai logo de Jerusalém... porque é para os gentios... que quero enviar-te"' (22,17-18.21). Esta visão, no templo, parece orientar o sentido do que acontecera no caminho de Damasco. Desapareceram a luz, a queda, a cegueira. Agora verificou-se uma experiência espiritual à qual ele acedeu estando em oração. E então conheceu o projeto de Deus: a missão aos gentios. A partir da experiência de Damasco Paulo estava predisposto ao encontro com Senhor em Jerusalém.

Seguindo esta primeira experiência fundante, o livro dos Atos mostra uma série de "visões", distintas do acontecimento de Damasco, mas vinculados a ele como desdobramentos conseqüentes. Tudo estava orientado à missão de evangelizar os gentios. Assim em 16,9-10 (visão do macedônio), ou então em 18,9-10 (missão em Corinto), ou ainda 23,11 (missão de testemunhar também em Roma). O que se pode observar nesta seqüência é que a partir do primeiro acontecimento, todas as vicissitudes enfrentadas por Paulo estavam sob a regência do Senhor Jesus.

Destas rápidas observações o que se pode dizer do que aconteceu a Paulo no caminho da perseguição, próximo a Damasco, faz parte "daquelas formas de comunicação religiosa que na tradição bíblico-judaica são apresentadas como visões e revelações de Deus. Trata-se de uma experiência de caráter religioso que implica, além do protagonista humano, uma referência à realidade de Deus, que por si não cai sob o controle dos sentidos e, portanto, não pode ser objeto de investigação historiográfica"3. . A credibilidade daquele evento pode ser constatada por aquilo que ele suscitou, isto é, uma mudança radical no modo de pensar e de agir de quem até então se destacava como perseguidor.

\subsubsection{Sentido teológico e existencial}

Mais de uma vez no seu epistolário Paulo faz menção daquela realidade surpreendente que o alcançou e o avassalou de um modo tal que alterou profunda e radicalmente o curso de sua vida. Mas em nenhum momento ele deixa vislumbrar traços psicológicos ou pormenores externos do que the sucedera. Tudo permanece sob as cortinas do silêncio. Quando escreve sobre o acontecido, já se vão aproximadamente vinte anos do fato. Mais do que recordação descritiva, após cuidadosa maturação, o apóstolo se ocupou em

\footnotetext{
${ }^{3}$ FABRIS, R.; Paulo, Apóstolo dos Gentios, São Paulo: Paulinas, 2001, pp. 161-162.
} 
interpretar tudo sob o signo da intervenção direta e imediata de Deus. Ademais, ao referir aquele acontecimento extraordinariamente singular, ele o faz de um modo tal que seu discurso se entrelaça intimamente com a exposição do seu Evangelho. Parece que o próprio Paulo quer ver relativizadas aquelas suas experiências individuais e psicológicas. Conta mais, para ele, que tudo aquilo seja visto nos quadros dos desígnios de Deus em vista do Evangelho de Jesus Cristo ${ }^{4}$. Foi um evento de pura graça $(1$ Cor 15,10).

Escrevendo aos Gálatas, Paulo indica qual era o conceito que, a partir do que experimentara em Damasco, ele tinha de si mesmo. Sublinha a iniciativa gratuita do Pai, a quem aprouve ( $\epsilon \dot{\delta} \delta \kappa^{\prime} \in \omega$ : comprazer-se; considerar bom) "separá-lo desde o seio materno" e o "chamou por sua graça" para que evangelizasse entre os gentios (1,15-16). Aquela foi à hora da gratuidade do seu chamado. A expressão "Desde o seio materno" relembra o chamado de Jeremias (Jr 1,5) e do Servo (Is 49,1.5). Desde Damasco a inteireza da vida do apóstolo recebera novo sentido e novo destino. A partir de então Paulo começava a reconhecer que não mais pertencia a si mesmo. Deus mesmo estava por trás de todos aqueles desdobramentos. E somente a partir dEle era possível compreender tudo quanto lhe sucedera ${ }^{5}$. A decisão soberana do Senhor se fazia conhecer somente naquele instante, mas era já um desígnio prefixado desde os primeiros instantes de sua existência. Por isso mesmo o "seu evangelho" não podia ser colocado em dúvida.

Em 2Cor 4,6 Paulo alude ao mesmo fato de Damasco em termos de uma nova criação: "Do meio das trevas brilhe a luz! Foi Ele mesmo quem reluziu em nossos corações, para fazer brilhar o conhecimento da glória de Deus, que resplandece na face de Cristo". Na primeira criação Deus fizera surgir a luz no caos primordial. Em Damasco Deus fizera surgir a luz no coração de Paulo, cujo brilho procede do encontro com Jesus Cristo. Daí em diante ele passou a "conhecer a glória de Deus". Conexo a tal "conhecimento" está também a missão.

Em diálogo com os Filipenses, Paulo indica que no caminho de Damasco "foi alcançado por Jesus Cristo" (Fl 3,12). Então aderiu a Ele. Sua história pessoal fora, a partir daquele momento, colocada sobre outros trilhos. Suas forças e energias visaram participar dos sofrimentos de Jesus Cristo e de sua ressurreição, pois que fora encontrado pelo Ressuscitado (v. 11). A adesão apaixonada de Paulo desencadeou uma total mudança em sua vida. Sua linguagem forte retrata a intensidade da reviravolta: o que era "lu-

\footnotetext{
${ }^{4}$ BORNKAMM, G.; Paulo, vida e obra, Petrópolis: Vozes, 1992, pp. 44-45.

${ }_{5}^{5}$ Para uma pormenorizada compreensão de G1 1,15-16 ver MUSSNER, F.; La Lettera ai Galati, Brescia: Paidéia, 1987,pp. 151-167. Também BUSCEMI, A.M.; Lettera ai Galati. Commentario Esegetico, Jerusalém: Franciscan Printing Press, 2004, pp. 109-124.
} 
cro" tornou-se perda. O que antes plenificava sua vida, o que considerava santo, pelo qual havia lutado com todas as suas forças, desfigurou-se em "esterco" $(3,7.8)$.

$\mathrm{Na}$ realidade, a conversão desencadeada por aquele encontro redirecionou absolutamente a vida de um homem já profundamente religioso. $\mathrm{O}$ fariseu zeloso, que cultuava a Lei mosaica, na verdade estava voltado sobre si mesmo. Para alguém tão destacado no farisaísmo, mais do que seus coetâneos (Gl 1,14), Deus teria coroado os seus méritos. A observância plena e minudente da Lei fazia dele um homem com muitos "direitos" diante de Deus. Tratava-se, pois, de confiança em si mesmo, dito melhor, era autosuficiência religiosa ou orgulho autocrata de quem acedia, por suas próprias forças, à salvação.

Para um judeu de tantos brios religiosos, aferrado à Lei e seguro de sua fidelidade, o novo caminho requeria muita luta interior. Somente uma experiência muito intensa e muito forte poderia sustentar seu novo percurso. Quem antes era "maldito" porque fora "suspenso ao madeiro" (Gl 3,13) revelou-se como Salvador crucificado e ressuscitado. É a Ele que então Paulo entregou-se em obediência de fé. A única medida da verdade do homem era o dom de Deus revelado em Jesus Cristo. Por isso mesmo a vida do "alcançado pelo Senhor" recebeu uma outra expressão e sentido: "Já não sou eu que vivo, mas é Cristo que vive em mim" (Gl 2,20).

Lendo com atenção os textos paulinos é possível reconhecer os traços psicológicos típicos do convertido: "Adesão total à nova causa e polêmica denúncia da falsidade da posição sustentada anteriormente; forte e inabalável consciência da coerência da escolha feita; segurança e coragem, não obstante inúmeras adversidades e contestações. Fruto de uma descoberta pessoal, sua fé se apresenta vigorosa e cálida de amor. Ao mesmo tempo é intolerante e severo nos confrontos com os adversários" ${ }^{3}$. Compromissos de conveniência e meias medidas não eram de sua têmpera.

1.2. De perseguidor dos primeiros cristãos a perseguido por causa do seu Senhor

Por várias vezes o livro dos Atos deixa ler alguns traços das disposições interiores de Paulo em relação aos seguidores de Jesus antes de ser "alcançado por Jesus Cristo". A primeira menção está em 7,56.8,1. Para evitar de colocá-lo como participante ativo no apedrejamento do primeiro mártir, Estevão, ele é apresentado como alguém que aprova a punição violenta $(8,1)$

${ }^{6}$ BARBAGLIO, G.; Le Lettere di Paolo, Roma: Borla, 1987, v. 1, p.22. 
a quem, supostamente, falava contra o templo e contra a Lei (cf. At 6,13).

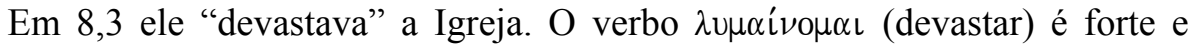
comporta a idéia de violência física e moral ${ }^{7}$. Usado no imperfeito indica uma atividade continuada, não limitada a fatos isolados.

As outras narrativas estão ligadas à experiência de Damasco. Em 9,1-2 as frases indicam comportamentos de virulência ainda maior do que "devastar a Igreja". Assim se lê: "Saulo, respirando ainda ameaças de morte contra os discípulos do Senhor..., pediu cartas para as sinagogas de Damasco".

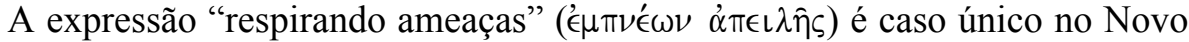
Testamento ${ }^{8}$. Equivale a "estar repleto de" e sugere algo do comportamento animoso do futuro apóstolo. Ele estava inteiramente tomado pelo seu projeto de zelar pela Lei a qualquer custo e em qualquer lugar. Para tanto afiguravam-se-lhe como acertados os seus ânimos violentos.

É por isso que nos outros dois relatos, expressos em forma de apologia, o Paulo lucano fala das motivações de fundo que suscitavam nele movimentos tão fortes perseguição. Em At 22,4 se lê: "Persegui de morte o este Caminho, prendendo e lançando à prisão homens e mulheres...". Por estas palavras vê-se que os gestos concretos eram prender e lançar à prisão; todavia os sentimentos e intenções visavam a destruição do assim chamado $\mathrm{Ca}$ minho ("persegui de morte"). E tais escolhas se explicavam porque Paulo era "cheio de zelo por Deus" $(22,3)$.

Nesta mesma direção seguem as palavras ante o rei Agripa, sempre em tom de apologia: "Parecia-me necessário fazer muitas coisas contra o nome de Jesus... Quando eram mortos eu contribuía com o meu voto... por meio de torturas quis forçá-los a blasfemar; e, no excesso do meu furor, cheguei a persegui-los em cidades estrangeiras" (At 26,9-11). Para dizer que se lhe afigurava "necessário" hostilizar o nome de Jesus, Paulo emprega o verbo $\delta \in \hat{L}$, que no Novo Testamento é característico para aludir a um desígnio divino. Em confronto com os textos anteriores, percebe-se que a atividade do perseguidor enquadra-se em uma espécie de "crescendo narrativo" nas diversas dimensões: no ódio, na extensão, na gravidade e variedade dos suplícios.

Não Lucas, mas o próprio Paulo refere a sua obstinação perseguidora. Em Gl 1,13, Paulo recorda a sua "conduta de outrora, no judaísmo, de como

\footnotetext{
${ }^{7}$ HENGEL, M., Il Paolo precristiano, Brescia: Paideia, 1993, p.167s.

${ }^{8}$ ROSSÉ, G.; Atti degli Apostoli. Commento Esegetico e Teológico, Roma: Città Nuova,

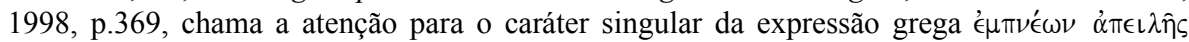
("respirar ameaças"). Trata-se de um caso único no Novo Testamento. Provém da linguagem literária grega (não popular). Escrito em forma participial o verbo ' $\epsilon \pi \nu \epsilon^{\prime} \omega+$ genitivo é muito próximo à forma "estar repleto de" + genitivo.
} 


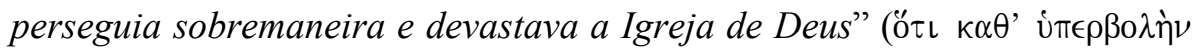

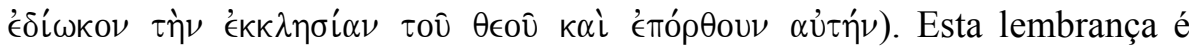
feita em relação ao discurso apologético sobre a origem e fundamento do seu evangelho. Perseguir "sobremaneira" ( $\kappa \alpha \theta$ ' i $\pi \epsilon \rho \beta 0 \lambda \eta े \nu)$ é uma expressão preposicional que ressalta o comportamento fanático durante a perseguição. É como se Paulo quisesse dizer "perseguia fanaticamente". O verbo "devastar", usado no imperfeito ('€mópӨouv) tem um sentido de ação progressiva e final ${ }^{10}$, ou seja, Paulo perseguia fanaticamente a Igreja de Deus, intencionado a destruí-la.

Um segundo texto da mão do próprio Paulo em que é mencionado o seu passado de perseguidor é Fl 3,6: "Quanto ao zelo, (era) perseguidor da Igreja". Esta linha faz parte do mais preciso conjunto de informações sobre o histórico judaico do apóstolo. Paulo orgulha-se de sua própria história. Ela consta de três qualidades congênitas (F1 3,5: "do povo de Israel; da tribo de Benjamim; hebreu, filho de hebreus"), e outras três adquiridas (3,6: "quanto à Lei, fariseu; quanto ao zelo, perseguidor da Igreja; quanto à justiça que há na Lei, irrepreensivel"). Aqui o perseguidor aparece sem especificações. Apenas mostra que é o $\zeta \hat{\eta} \lambda$ oఢ que determina e qualifica o papel de Paulo como perseguidor. As frases são sumárias, abreviadas. Mas não escondem uma personalidade excitada e impetuosa. Sua linguagem se aplaca, porém, no verso seguinte (v. 7: “...o que era para mim lucro, tive-o como perda, por amor de Cristo"). Com isso quer ele indicar que somente em Jesus Cristo sua vida alcançou um equilíbrio estável ${ }^{11}$.

Também em 1Cor 15,9 a menção de Paulo sobre o passado de perseguidor está matizada pela graça. O Senhor Ressuscitado aparecera também a ele. Por isso se reconhece como apóstolo, ainda que não digno, porque "perseguiu a Igreja de Deus". Mas "pela graça de Deus sou o que sou" (v. 10). Neste caso a acentuação incide na nova condição pessoal que a eleição como apóstolo lhe agraciou. Se antes ele era "como um abortivo" (v.8) o encontro com o Senhor, ainda que perseguidor, fora algo tão extraordinário como uma criança, já morta, nascer para a vida. E o antigo perseguidor aderiu à graça a ponto de trabalhar "mais que todos eles" (v.10).

Todas estas notícias acerca do vigor persecutório de Paulo estão inseridas em narrativas ou reflexões relativas à nova história, e ao novo homem, que começou a ser forjado a partir de Damasco. Mas a linguagem empregada indica que ele se empenhava por completo e estava totalmente absorto no

\footnotetext{
${ }^{9}$ BUSCEMI, A.M.; Lettera ai Galati. Commentario Esegetico, p. 93.

${ }^{10}$ LÉGASSE, S.; L'Êpitre de Paul aux Galates, Paris: Cerf, 2000, p. 85.

${ }^{11}$ GNILKA, J.; La Lettera ai Filippesi, Brescia: Paidéia, 1972, pp. 313-314.
} 
que se tornara uma "atividade habitual"12. Todavia, para falar ao modo do próprio Paulo, em Damasco o Senhor se "revelou" a ele (Gl 1,12); deu-se a conhecer. E tal revelação estava orientada a constituir Paulo como o evangelizador dos gentios $(1,16)$. Ao cristão de Damasco, Ananias, o Senhor insistiu: "Vai, porque este homem é um instrumento de minha escolha para levar o meu nome... Eu mesmo lhe mostrarei quanto lhe é preciso sofrer em favor do meu nome" (At 9,15-16). Conversão, chamado ao ministério e caminho de cruz, estavam inseparavelmente unidos.

Em termos concretos, para o até então perseguidor tudo aquilo significaria integrar na própria existência o destino do perseguido. Paulo é discreto ao extremo em falar das vivências subjetivas daqueles dias de Damasco, mas o tempo mostrou que foi a mais esmagadora experiência de sua vida. A partir de então, avassalado por seu Senhor, ei-lo familiarizado com a existência do evangelizador perseguido. É justamente o que confessa em 2Cor 11,2328 , num confronto comparativo entre o seu ministério e o de seus adversários. Nos quadros da missionariedade do cristianismo nascente, o ministério de Paulo tornou-se mais credível porque se destacou pelas "fadigas... prisões... açoites... cinco vezes os quarenta golpes menos um... três vezes flagelado... uma vez apedrejado... três vezes naufraguei... perigos por parte dos meus irmãos de estirpe, perigos dos gentios... perigos dos falsos irmãos... numerosas vigílias, fome e sede...".

\subsection{A relação pessoal com Jesus Cristo}

Não se pretende aqui apresentar um levantamento dos textos paulinos que indiquem características e particularidades da relação pessoal do apóstolo com Jesus Cristo. Não é esta análise que se quer fazer. Não se buscam aqui os delineamentos de sua espiritualidade. O objetivo é outro; é destacar quanto a relação com Jesus Cristo tinha incidências em sua vida ministerial, com desdobramentos efetivos sobre a vida de fé dos seus leitores. Para tanto parte-se de um exemplo, entre vários possíveis: Fl 3,7-8.4,9.

Trata-se de versículos componentes da assim chamada "carta polêmica" (Fl 3,1-4,1.8-9). Deixando a parte os longos debates e hipóteses de crítica literária, a atenção se volta para as palavras do autor: 7"Mas o que era para mim lucro, tive-o como perda, por causa de Cristo. 8Mais ainda: tudo considero perda, pela excelência do conhecimento de Cristo Jesus, meu Senhor. Por ele, perdi tudo e tudo tenho por esterco, para ganhar a Cristo".

${ }^{12}$ Murphy O'Connor, OP; Paulo, biografia crítica, p. 81. 
A linguagem é apaixonada. O contexto é o de combate aos contramissionários, de tendência judaizante, que se atuavam também em Filipos. E Paulo, muito empenhado na defesa da comunidade, apresenta-se como um exemplo a imitar. Os filipenses são instados a aprender do seu passado, mas também do fato de que ele se deixa ainda no presente, e até com maior intensidade, a portar-se decisivamente segundo sua escolha por Jesus Cristo. O apelo aos cristãos é que se deixem estimular por ele, por sua história, por suas opções.

"Mas o que era para mim lucro, tive-o como perda, por causa de Cristo". Não resta dúvida de que aqui ele alude à sua experiência de Damasco. Todavia, mais do que recordar o evento de graça, acontecido no passado, as palavras escolhidas ressaltam particularmente sua decisão pessoal e revolucionária ${ }^{13}$. Uma decisão por Jesus Cristo. A expressão "por causa de Cris-

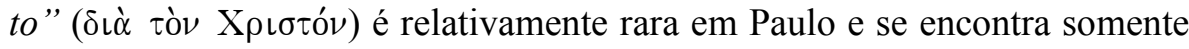
naqueles textos em que o apóstolo quer salientar o caráter paradoxal de suas ações $^{14}$. Estão em jogo não apenas meios humanos ou pessoais de Paulo. $\mathrm{O}$ emprego de tal sentença assegura o caráter de graça. Mas ele enfatiza tam-

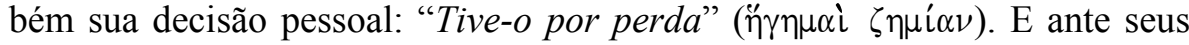
olhos estão presentes, além de sua história pessoal, também os cristãos de Filipos. Eles são interpelados a se deixar ensinar por aquela experiência. Devem decidir como ele.

O alcance de tal decisão é ilustrado pela polaridade ganho-perda. Para Paulo tratou-se de uma guinada radical, de uma inversão dos valores. Foi algo bem diverso do que passar do bom ao melhor. Foi bem mais do uma forma parcial de despojamento. Tratou-se de reconhecer que aquelas coisas que tinha por vantagem, que eram motivo de honra e grandeza, na realidade foram-lhe danosas. Percebera ele que seus esforços religiosos e morais foram desqualificados ante a experiência de encontro com Jesus Cristo. Aliás, aquelas "conquistas pessoais" (cf. Gl 1,14) mais favoreciam o orgulho espiritual, que terminava pela rejeição da graça de Cristo. Fora exatamente esta a sua vivência. E ele, Paulo, desejava que seus leitores filipenses, que também se fizeram cristãos, assumissem como suas as escolhas dele.

Isso pode ser observado no v. 8. O texto vai do passado ao presente (v. 7: "tive-o por perda" / v. 8: "considero perda"), além de ampliar o conteúdo do anterior: "mais ainda"... tudo considero... perdi tudo... tudo tenho". Sua experiência antiga fora, ao longo do tempo, confirmada e largamente reforçada, a ponto de abarcar a totalidade de sua existência. O centro unificador é

${ }^{13}$ GNILKA, J.; La Lettera ai Filippesi, Brescia: Paidéia, 1972, pp. 317.

${ }^{14}$ Exemplos semelhantes podem ser encontrados em 1Cor 4,10: "Nós estultos por amor de Cristo"; 2Cor 4,5: "Vossos escravos por amor de Cristo". 


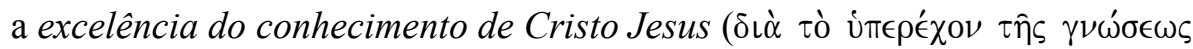

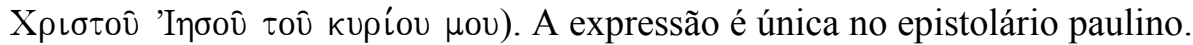
Não se trata de acesso intelectual. Tampouco se exauriu no caminho de Damasco, quando e onde tudo começou. Trata-se de uma força que plasma com eficácia sua vida presente, que parte de uma experiência pessoal vivida e renovada. É um conhecimento de caráter bíblico, isto é, vinculante, que comporta comunhão de vida, que empenha totalmente a pessoa e sua liberdade em um processo de transformação pessoal.

Aliás, o caráter personalizado é também reforçado pela referência a "Cristo Jesus, meu Senhor". Também esta fala é única nas cartas de Paulo. E indica bem a condição de pertença do apóstolo, que passara da antiga observância à plena obediência. Daí segue sua linguagem, sempre bem matizada por polarizações. Tudo o que não o aproxima de Cristo é tido por perda (referência ao seu passado: "perdi tudo") ou esterco (referência ao seu presente: "tenho por esterco"), se não for "para ganhar a Cristo".

Vale ainda recordar que na frase final "para ganhar a Cristo", de matiz mais genérico, todos os leitores de Paulo podem se reconhecer orientados ao mesmo objetivo. O discurso em primeira pessoa, além da "confissão", tem também um sentido de exemplaridade ${ }^{15}$. Isso receberá forma explícita alguns versículos depois, em 3,17: "Sede meus imitadores, irmãos, e observai os que andam segundo o modelo que tendes em nós". Há uma unidade plena entre palavra e exemplo, pois que este confere à palavra a eficácia do testemunho.

\section{O Conflito de Antioquia}

Ao se lançar um olhar sobre Paulo e seu influxo no cristianismo nascente, com certeza o contraste de Antioquia insere-se entre os de maior notoriedade. Subjacente aos fatos, aparentemente incidentais, estabeleceu-se uma difícil e espinhosa controvérsia, com desdobra-mentos temáticos e doutrinais que perpassam larga parte do epistolário paulino. As informações disponíveis são bastante rarefeitas. As presentes em At 15,1-35, referentes à assembléia de Jerusalém, afiguram-se a uma coletânea, bastante otimista, de acontecimentos distintos e dispersos, mas de complexidade bem maior do que o apresentado pelos textos. Em Antioquia a problemática ressurgiu com grande virulência. Lá estavam novamente Pedro e Paulo. Do quanto se sabe, foi o último encontro que tiveram entre si. E terminou em conflito. Não se tratava de questões de caráter pessoal. $\mathrm{O}$ que estava em jogo era o modo concreto e

\footnotetext{
${ }^{15}$ Cf. GNILKA, J.; La Lettera ai Filippesi, pp. 320-321.
} 
efetivo daqueles cristãos, filhos da Igreja nascente, acederem à salvação. Tinha ainda a Lei judaica alguma virtude salvífica? Ou é somente Jesus o mediador da salvação?

$\mathrm{O}$ texto chave a partir do qual se abordou e se interpretou toda aquela sucessão de incidentes é Gl 2,11-14. A importância histórica e teológica destes versículos pode ser avaliada pela intensa literatura que suscitou. Ao longo da história, especialmente a partir da Reforma, estão estes versículos entre os textos mais comentados pela exegese. Cada palavra e frase foram minudentemente lidos e relidos, interpretados e reinterpretados, com grandes disparidades nas conclusões, algumas com exageros, outras com muitos anacronismos, e há casos até de paixões confessionais ${ }^{16}$. Joachim Gnilka até recorda um comentário de W. Schenk acerca do texto em causa: "Dize-me como tratas Gl 2,11-14 e te direi que cristão és"17.

Tanta variedade se explica pela escassez textual, associada às grandes conse-qüências para o cristianismo dos primeiros tempos ${ }^{18}$; ademais, a passionalidade com que Paulo afronta a temática também favoreceu a multiplicidade hermenêutica. A questão pode ser reconstruída nos seguintes passos: após a assembléia de Jerusalém, Paulo e Barnabé retornaram a Antioquia (At 15,35). Tempos depois também Pedro chegou à cidade (G1 2,11); participava das refeições com os gentios $(2,12)$. Tais refeições comuns tinham grande força unificadora entre os cristãos vindos do judaísmo e aqueles provenientes da gentilidade. Mas apareceram alguns vindos da parte de Tiago $(2,12)$. Então Pedro, paulatinamente, deixou de tomar parte em tais encontros, por temor dos circuncisos $(2,12)$. Outros judeus começaram a "fingir com ele", a tal ponto que até mesmo "Barnabé se deixou levar pela sua hipocrisia" $(2,13)^{19}$. Por isso mesmo Paulo afrontou Pedro publicamente $(2,14)$. Para ele,

\footnotetext{
${ }^{16}$ Um excelente panorama sobre a variedade de interpretações de Gl 2,11-14, partindo desde os primeiros séculos do cristianismo até os anos recentes, pode ser encontrado em MUSSNER F.; LA Lettera ai Galati, Brescia: Paideia Editrice, 1987, pp. 241-272. Para interpretação estritamente exegética do texto, recente e atualizada, recomenda-se BUSCEMI A. M.; La Lettera ai Galati, commentario esegetico, Jerusalém: Franciscan Printing Press, 2004, pp. 181-194.

${ }^{17}$ GNILKA J.; Pablo de Tarso, Apóstol y testigo, Barcelona: Herder, 1998, p. 102.

${ }^{18}$ De fato a problemática dos judaizantes perpassa toda a epístola aos Gálatas, mas está também muito presente na segunda epístola aos Coríntios, e também Filipenses, além de Romanos, ainda que em teor menos passional e mais sistemático. Até o famigerado "espinho na carne", de 2 Cor 12,7, por longo tempo considerado como uma doença crônica, é identifícado por muitos autores com a atuação dos cristãos judaizantes, que solapavam o trabalho missionário e catequético de Paulo.

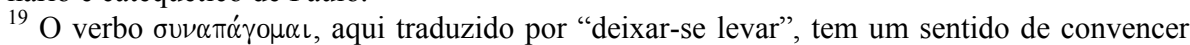
alguém a mudar de convicções. Tais mudanças estão orientadas a fazer alguém crer no que é
} 
tanto Pedro, quanto Barnabé e os outros judeus, não se portavam com retidão "segundo a verdade do evangelho" $(2,14)$.

Ao que parece, somente Paulo, um judeu cristão, posicionou-se com os cristãos vindos da gentilidade. A comunidade se encontrava profundamente dividida, pois comunhão de mesa é comunhão de vida ${ }^{20}$. A temática central não era, pois, de índole meramente social, vinculada a comidas. Era uma questão teológica fundamental. Estava em jogo a "verdade do Evange1ho". Embora os fiéis de origem pagã tivessem aderido a Jesus Cristo, os missionários de Jerusalém, por sua atitude, não os reconheciam como "justificados". Para eles os irmãos vindos da gentilidade teriam que se integrar aos balizamentos da Lei judaica, como se a fé em Jesus Cristo não bastasse para a salvação. Isso equivalia a diminuir a potência salvífica da morte e ressurreição de Jesus Cristo e conferir à Lei judaica um vigor soteriológico que a mesma não tinha. Em Antioquia a Lei estava se tornando um falso, mas perigoso rival de Cristo, até chegar ao ponto de neutralizá-lo. "Se é pela Lei que vem a justiça, então Cristo morreu em vão" $(2,21)$ e a graça de Deus seria invalidada. Sem a Lei, os gentios que se fizeram cristãos continuariam pecadores e, por extensão, Cristo seria ministro do pecado $(2,17)$. Por estas razões Paulo jamais se compaginou com quem reconhecia legitimidade na "judaização" do cristianismo. Não era uma questão ideológica, era teológica. Para ele a morte e ressurreição de Jesus eram de um porte totalizante e único, sem condivisões.

Paulo não menciona como terminou o conflito. Mas se tivesse tido um final feliz, muito provavelmente teria ele referido aos gálatas. Do quanto se pode deduzir por outras epístolas, a problemática se estendeu. Pelas informações disponíveis, Paulo deixou Antioquia (At 15,40) e não mais retornou. Mas não é acertado falar de vencedor e vencido. Não foi um confronto interpessoal. Sim, deve ter sido muito doloroso para Paulo, mas ao que parece, de sua parte não houve ruptura completa. Manifestações posteriores assim sugerem (1Cor 9,5ss; 15,1-11). Porém, o sinal mais enfático do desejo de se manter em unidade expressou-se na realização da coleta em favor dos "santos" (G1 2,10; 1Cor 16,1; 2Cor 8,4; 9,1) de Jerusalém. Neste gesto de solidariedade fraterna, Paulo se reconheceu em um "serviço para a glória do Senhor e

falso. Cf. LOUW J. P. - NIDA E. A., Greek-English Lexicon of the New Testament Based on Semantics Domains, New York, 1988.

${ }^{20}$ MURPHY O’CONNOR, J.,OP, Paulo, biografia crítica; São Paulo: Loyola, 2000, p. 161, explica que "no Antigo Oriente Próximo, uma refeição formal era o mais importante evento social. Partilhar a comida era reforçar ou iniciar um laço social que significava dedicação permanente e profunda obrigação ética. Aos olhos dos seus contemporâneos, não haveria nenhuma comunidade genuína entre os cristãos, a menos que, além do ritual da Eucaristia, eles se reunissem em torno de uma mesa comum". 
realização das nossas boas intenções" (2Cor 8,19). Ele compreendera que "em Cristo Jesus, nem a circuncisão tem valor, nem a incircuncisão, mas a fé agindo pela caridade" (Gl 5,6).

\section{3. "Os judeus pedem sinais, os gregos buscam sabedoria. Nós, porém, proclamamos Cristo Crucificado...” (1Cor 1,22-23)}

Os evangelistas sinóticos relatam alguns traços típicos e críticos da experiência do discipulado que, sob outro formato, são encontradiços também nas comunidades paulinas. Em caminho para Jerusalém, Jesus ensinava aos discípulos acerca da realidade de cruz e ressurreição que lá se verificaria. Em flagrante contraste com o ensinamento recebido, dois deles, ansiosos pela "glória" do seu "Mestre", pedem para ocupar a direita e a esquerda do Senhor glorioso (Mc 10,32-34.35-40). Aceitar o paradoxo da cruz sempre foi um forte óbice ao cristianismo nascente, que golpeou também as comunidades paulinas. Esta temática se tornou explícita na comunidade de Corinto, na qual tendia a prevalecer o anseio de um cristianismo assinalado pela ênfase na glória, e matizado por caminhos planos e bem sucedidos. Os textos distribuem-se pelas duas epístolas, mas para os propósitos presentes, os versículos de 1Cor 1,22-23 afiguram-se suficientemente ilustrativos.

Já em 1,17 Paulo colocara a "sabedoria da palavra" e a cruz de Cristo em relação de contraposição: “... mas para anunciar o evangelho, sem a sabedoria da palavra para não ser esvaziada a cruz de Cristo" (oủk Ł́v бô

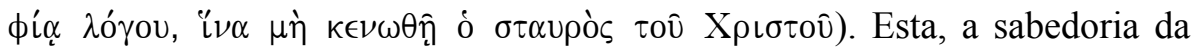
palavra, golpearia a genuinidade do próprio evangelho. Em uma série de seqüenciada de três parágrafos $(1,18-25 ; 1,26-31 ; 2,1-5)$, Paulo tenta fazer os coríntios perceberem que sua condição de cristãos interpelava-os a posicionamentos bem distintos do quanto reivindicavam seus anseios humanos. A cruz de Cristo não era apenas um nobre atributo a ser acrescentado à sabedoria humana, para enobrecê-la. Absolutamente mais que isso, era um predicado da existência cristã mesma. A cruz se contrapunha à sabedoria humana; por isso o apóstolo a classificava como loucura para o conceito humano de sabedoria. E o que era "loucura de Deus é mais sábio do que os homens, e o que é fraqueza de Deus é mais forte que os homens". Não há outro caminho para quem decidiu crer em Jesus Cristo. É este o contexto no qual se inserem os versículos 1,22-23.

No v. 22 Paulo confere indicações precisas acerca do que deixara vago no v. 18. Lá afirmara que a "linguagem da cruz é loucura para aqueles que se perdem", todavia, sem definir que são. Agora, no v. 22, os que "se perdem" estão basicamente divididos em dois grupos, um que reflete a visão 
judaica do mundo e o outro a grandeza humana expressa em sabedoria. Tanto uns quanto outros desenvolveram motivos que intervinham na recusa da palavra da cruz. Para a mentalidade judaica a humanidade se subdividia em judeus e gregos, em analogia com a classificação grega, que classificava a humanidade em gregos e bárbaros. Ambos os grupos humanos queriam provas da verdade divina. Judeus e gregos ilustravam, pois, as idolatrias básicas da humanidade. Deus atuaria como um ente "todo-poderoso" ou dotado da plenitude da sabedoria, mas sempre nos termos dos melhores interesses humanos $^{21}$.

No que concerne aos reclamos de sinais por parte dos judeus, isso implicava em uma recusa de confiança em Deus. Ele deveria se apresentar com credenciais sob forma de sinais visíveis e identificáveis, mediante os quais poderia demonstrar a validez de sua pretensão sobre os homens e sua capacidade de satisfazer suas necessidades ${ }^{22}$. Embora sem explicitar, seria Deus quem deveria se conformar e se ajustar aos padrões judaicos. Atitudes assim, por mais que se afigurassem religiosas, eram, fundamentalmente, céticas e egotistas. Conservavam ainda a mentalidade dos tempos do AT, segundo a qual o Messias restauraria a antiga glória, mediante gestos de plenipotência em favor dos eleitos. Os sinais seriam como demonstrações de potência divina que legitimariam Jesus como o Messias esperado. O pretendente messiânico seria autenticado se as forças celestiais o ajudassem a obter a vitória sobre os inimigos e a instaurar o senhorio de Deus. A partir do momento em que falta esta legitimação a Jesus crucificado, a Ele não é sensato aderir; aliás, seria um pensamento quase blasfemo.

Já os gregos, indagadores por excelência da origem das coisas, buscavam a sabedoria e a inteligência da ordem intrínseca do universo. Por esta via alcançariam a essência da divindade ${ }^{23}$. Para aceitar Jesus buscavam, pois, a iluminação. Em termos de compreensão intelectual das coisas, os gregos eram tão evoluídos como ninguém antes deles. E por sua maturidade de pensamento muitos abandonaram os deuses tradicionais para dedicarem-se à sophia ou philosophia. Sua idolatria era conceber Deus como a última Razão, conferindo ao ato de crer um sentido de racionalidade ${ }^{24}$. E tornar-se cristão seria uma grande possibilidade desde que a mensagem de Jesus Cristo se ajustasse à sua lógica e sabedoria.

\footnotetext{
${ }^{21}$ FEE, G. D.; The First Epistle to the Corinthians, Grand Rapids: William Erdamns Publishing, 1991, p. 74.

${ }_{22}$ BARRET, C. K.; La Prima Lettera ai Corinti, Bologna: Dehoniane, 1979, p. 75.

${ }^{23}$ LANG F.; Le Lettere ai Corinti, Brescia: Paideia Editrice, 2004, p. 49.

${ }^{24}$ FEE, G. D.; The First Epistle to the Corinthians, p. 75.
} 
Mas a quem queria sinais autenticadores ou tudo condicionava à sabedoria iluminadora para penetrar na essência do divino, Paulo tinha uma resposta única e definitiva, certamente ligada às suas experiências pessoais de encontro com o Senhor e de conhecimento de sua cruz. Ela, a cruz de Jesus, não atendia a nenhuma daquelas condições dos judeus ou dos gregos; aliás, era absurdo para ambas. Escândalo e loucura a definiam bem para a mentalidade vigente em Corinto. Mas Deus não revelou sua potência e sabedoria apenas na criação do mundo e na condução da história, mas de modo único e especial no evento Cristo. Para a lógica humana a cruz de Cristo não demonstra nem potência nem sabedoria. Mas a quem passa a conhecer a Deus a partir de Jesus ela responde a estas duas prerrogativas.

Mas era preciso despojamento. Na mente judaica não era possível conviver messianismo e cruz. O primeiro significava força, esplendor, triunfo. A segunda comportava humilhação, fraqueza, tropeço. Historicamente, para Jesus a cruz significou o fim trágico dos malfeitores. Para os padrões judaicos seu fim foi o dos "malditos" (Dt 21,23; Gl 3,13). Rejeitá-lo era até uma questão de obediência à Lei (Dt 27,26; Gl 3,10). Não havia caminhos mediante os quais Jesus crucificado se enquadrasse nas tradições das Escrituras. Era, pois, uma grande pedra de tropeço.

Já para os gregos, mas também para os romanos a idéia de "Jesus Crucificado" tem um teor de "perniciosa superstição" (Tácito), ou uma "perversa e extravagante superstição" (Plinio, o jovem), de loucura (v. 23: $\mu \omega \rho^{\prime} \alpha$ ). Henge $^{25}$ faz notar que o termo "loucura" não denota apenas imperfeição intelectual, ou também, insuficiência de sabedoria transcendental. O sentido é de demência, de estupidez. Como aceitar um Filho de Deus crucificado?!? Isso se contrapunha a tudo quanto se sabia acerca de Deus ${ }^{26}$. Mas para Paulo, que se opunha a qualquer concepção que minimizasse a cruz, a cruz de Jesus, morto e ressuscitado se constituiu em uma espécie de "ponta do diamante" (M. Hengel) do seu anúncio ${ }^{27}$. O evangelho como palavra da cruz é uma espécie de "apocalipse do homem" $"$. $\mathrm{O}$ encontro do homem com o evange-

\footnotetext{
${ }^{25}$ Citado por FEE, G.D.; The First Epistle..., p. 76.

${ }^{26}$ EICHHOLZ G.; El Evangelio de Pablo, Salamanca: Sigueme, 1977, p. 103, recorda a ênfase de Paulo sobre a pré-compreensão que judeus e gregos tinham de Deus. Tal précompreensão os faz passar ao largo da realidade mesma de Deus, aquela que lhes saíra ao encontro na cruz de Jesus Cristo. O Deus real, é aquele que vai à procura do homem. Mais do que o homem perguntar por Deus, trata-se de deixar Deus perguntar pelo homem.

${ }^{27}$ É de grande relevância observar o modo freqüente, quase um "estribilho paulino", mediante o qual o apóstolo reage ante as oposições judaico-cristãs que se interpõem ao seu programa missionário. A cruz de Jesus e o seguimento ao crucificado são evocados sempre como expressão de fidelidade (Gl 6,14; ICor 4,9-13; 2 Cor 4,7-10; 6,4-10; 11,23-29; Rm 8,35-36).

${ }^{28}$ EICHHOLZ G.; El Evangelio de Pablo, p. 102.
} 
lho (ou o inverso, o do evangelho com o homem) vê-se ele interpelado se aceita ou não a decisão de Deus a seu respeito. Vai dizer sim ao modo de Deus, ou vai recusá-lo.

Tais percepções não resultam de teorizações abstratas de Paulo. São desdobra-mento de um combate contra suas próprias pré-compreensões e projeções. Em Gl 6,14, sempre em tom forte, ele refere seu ideograma: "Mas longe esteja de mim gloriar-me, a não ser na cruz de nosso Senhor Jesus Cristo, pela qual o mundo está crucificado para mim e eu para o mundo". Somente na cruz de Cristo radica-se a fonte do seu prestígio diante de Deus, e não em alguma obra da lei ou da sabedoria humana. A sentença "longe de

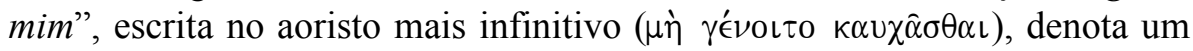
modo de falar orientado a rechaçar radicalmente alguma coisa. Mediante a cruz de Jesus Cristo, o mundo como um todo, como soma e forma das possibilidades terrenas, está morto para ele. E também ele, Paulo, já morrera para mundo porque este se tornara impotente diante da cruz de Cristo. Suas autoafirmações estão vinculadas à cruz do Senhor. "Gloriar-se na cruz de Cristo" não era uma exageração pessoal da realidade, ou uma expressão de autosuficiência religiosa. Cristo se tornara o fundamento de sua existência, por quem era capaz de viver e de morrer.

Todavia, a cruz se não interpretada em relação com a ressurreição permaneceria sob os esquemas da "loucura humana". Para quem crê, para os "chamados" (v. 24), quer judeus ou gregos, Deus confirmou o Cristo crucificado com o ato da ressurreição. É por esta via que a cruz se torna instrumento da potência e sabedoria de Deus. Esta sabedoria Paulo a apresentou sob forma de máxima, baseada na infinita superioridade de Deus sobre todas as suas criaturas: "O que é loucura de Deus é mais sábio do que os homens, e o que é fraqueza de Deus é mais forte do que os homens". Em outras palavras, a judeus e a gregos, o apóstolo instava os primeiros cristãos a deixar Deus ser "seu Deus" mediante as opções que Ele assumira em seu Filho Jesus Cristo.

\section{Conclusão}

Parece fácil notar que atividade incansável, sempre criativa e bem motivada atividade evangelizadora de Paulo, em meio a muitas adversidades, era sustentada por uma alentada relação pessoal com Jesus Cristo. E o fato fundante foi a experiência de Damasco. Foi naquele encontro que começou, e que conheceu desdobramentos surpreendentes, todo o seu dinamismo espiritual. 
Como grande protagonista do cristianismo nascente, muito se poderia dizer de sua reflexão e teologia de grande calado. Mas jamais Paulo teria se tornado o grande evangeli-zador, o grande mestre e educador da fé, se não tivesse conservado consigo, em sua memória afetiva, a grandeza e profundidade de seus encontros com Jesus Cristo. A grande estatura intelectual, está ligada, sem dúvida à dúplice matriz cultural que o forjou nas habilidades de caráter reflexivo. Todavia, foi no encontro com o Senhor, começado nas proximidades de Damasco, mas sustentado e renovado nos seus caminhos missionários.

O próprio Paulo sugere como era ele antes do encontro com Jesus Cristo. Já antes era um tipo de paixões fortes e decisões corajosas. Era apaixonado pelo judaísmo. Por isso "perseguia sobremaneira", chegava às raias do fanatismo. Parecia ser afeito à emulação, pois diz que "progredia mais que os compatriotas de minha idade" (Gl 1,14). Era-lhe interessante distinguir-se no zelo pelas tradições paternas. Em favor das mesmas até a violência recebia legitimidade. Mas o encontro com Jesus Cristo fizera dele um outro homem. E sua palavra passou a ter um caráter de exemplaridade. Nada passou a ter um sentido de grandeza a não ser a conformidade com Jesus Cristo, e Cristo crucificado. O critério de verdade vinculou-se decisivamente a esta realidade. E em sua vida passou a "levar em sua vida as marcas de Jesus". Paulo pode ser interpretado sob muitos esquemas, mas entre tanto legados que deixou ao cristianismo nascente, com grande convicção se pode dizer que ter partilhado o destino mesmo de Jesus, seu Senhor, foi talvez o mais expressivo ato de fidelidade.

\section{Bibliografia Consultada}

BARBAGLIO, G.; Le Lettere di Paolo, Roma: Borla, 1987.

; São Paulo, o Homem do Evangelho, Petrópolis: Vozes, 1993.

BARRET, C. K.; The Second Epistle to the Corinthians, London: A \& C Black, 1986.

BORNKAMM, G.; Paulo, vida e obra, Petrópolis: Vozes, 1992.

BUSCEMI, A.M.; Lettera ai Galati. Commentario Esegetico, Jerusalém: Franciscan Printing Press, 2004.

COSGROVE C. H.; "Did Paul value Ethnicity", Catholic Biblical Quarterly 68 (2006) 268-290.

EICHHOLZ G.; El Evangelio de Pablo, Salamanca: Sigueme, 1977.

FABRIS, R.; Paulo, Apóstolo dos Gentios, São Paulo: Paulinas, 2001. 
FORBES, C.; "Comparison, Self-Praise and Irony: Pausl's Boasting and the Conventions of Hellenistic Rethoric", New Testament Studies 32 (1986) 1-32.

GNILKA, J.; Pablo de Tarso, apóstol y testigo, Barcelona: Herder, 1998. ; La Lettera ai Filippesi, Brescia: Paideia, 1972.

HENGEL, M.; Il Paolo precristiano, Brescia: Paideia, 1993. ; Judaism and Hellenism: Studies in their Encounter in Palestine in the Early Hellenistic Period, Filadélfia: Fortress, 1974.

LANG, F.; Le Lettere ai Corinti, Brescia: Paideia, 2004.

LÉGASSE, S.; L'Êpitre de Paul aux Galates, Paris: Cerf, 2000. ; L'Êpitre de Paul aux Romains, Paris: Cerf, 2002.

MURPHY O'CONNOR, J., OP; Paulo, biografia crítica; São Paulo, Loyola, 2000. ;Paulo de Tarso. História de um Apóstolo, São Paulo: Paulus/Loyola, 2007.

MUSSNER, F.; La Lettera ai Galati, Brescia: Paideia, 1987.

PESCE, M.; As Duas Fases da Pregação de Paulo, São Paulo: Loyola, 1996.

ROSSÉ, G.; Atti degli Apostoli. Commento Esegetico e Teológico, Roma: Città Nuova, 1998.

SALDARINI, A. J., Pharisees, Scribes and Saudecees in Palestinian Society, Edinburgh: Clark, 1988.

SCHLIER H.; La Carta aos Galatas, Salamanca: Sígueme, 1975.

SCHNELLE, U.; A Evolução do Pensamento Paulino, São Paulo: Loyola, 1999.

SELAND, T.; "Saul of Tarsus and Early Zealotism Reading Gal 1,13-14 in Light of Philo's Writings", Biblica 83 (2002) 449-471.

Dom José Antônio Peruzzo

Atual Bispo da Diocese de Palmas, PR Doutor em Teologia Bíblica pela Universidade Santo Anselmo, Roma 